\title{
Women's Position Within the Household as a Determinant Of Maternal Health Care Use in Nepal
}

CONTEXT: Although gender inequality is often cited as a barrier to improving maternal health in Nepal, little attention has been directed at understanding how sociocultural factors may influence the use of health care. In particular, how a woman's position within her household may affect the receipt of health care deserves further investigation.

METHODS: Data on ever-married women aged 15-49 from the 2001 Nepal Demographic and Health Survey were analyzed to explore three dimensions of women's position within their household-decision making, employment and influence over earnings, and spousal discussion of family planning. Logistic regression models assessed the relationship of these variables to receipt of skilled antenatal and delivery care.

RESULTS: Few women reported participation in household decision making, and even fewer had any control over their own earnings. However, more than half reported discussing family planning with their husbands, and there were significant differences among subgroups in these indicators of women's position. Though associations were not consistent across all indicators, spousal discussion of family planning was linked to an increased likelihood of receiving skilled antenatal and delivery care (odds ratios, 1.4 and 1.3, respectively). Women's secondary education was also strongly associated with the greater use of health care (5.1-5.6).

CONCLUSIONS: Gender inequality constrains women's access to skilled health care in Nepal. Interventions to improve communication and strengthen women's influence deserve continued support. The strong association of women's education with health care use highlights the need for efforts to increase girls'schooling and alter perceptions of the value of skilled maternal health care.

International Family Planning Perspectives, 2006, 32(1):17-27
By Marie Furuta and Sarah Salway

Marie Furuta is lecturer, Department of Community Health Nursing, St. Mary's College, Kurume, Japan. Sarah Salway is senior lecturer, Department of Community, Ageing and Rehabilitation, School of Nursing and Midwifery, University of Sheffield, Sheffield, UK.
Maternal mortality in Nepal is estimated to be around 540 deaths per 100,000 births. ${ }^{1}$ One major factor is low use of maternal health care, despite government efforts to improve services, including an expanded network of rural clinics and the training of auxiliary nurse midwives. ${ }^{2}$ Fewer than 40\% of women receive any antenatal care from a trained provider, and fewer than $10 \%$ of births take place in a health facility. ${ }^{3}$

In seeking to explain these low levels of health care use, most research has focused on the provision and geographic accessibility of services. However, no studies have looked at how sociocultural factors, such as inequitable gender roles and women's position within the household, have influenced use of services.

Earlier work in South Asia has suggested various ways in which gender roles and relations may operate to restrict women's access to health care during pregnancy and at the time of delivery. These include heightened restrictions on women's movement because the pregnant state is considered "shameful," young women's lack of say within the family and the fact that pregnancy-related knowledge and decision-making authority are commonly vested in older women, young women's lack of influence over material resources, and the exclusion of men, who are often the primary decision makers in the use of material resources, from the "polluting" event of childbirth. ${ }^{4}$ In addition, a growing body of literature has explored the links between indicators of women's household position and contraceptive use in South Asia. ${ }^{5}$ However, little of this research has examined whether and how dimensions of women's position are related to their use of maternal health care services.

It is widely asserted that increased gender equality is a prerequisite for achieving improvements in maternal health. The Programme of Action adopted at the 1994 International Conference on Population and Development claimed that "improving the status of women also enhances their decision-making capacity at all levels in all spheres of life, especially in the area of sexuality and reproduction." In Nepal, the low social status of women has been identified as a hindrance to progress toward national health and population policy targets. ${ }^{7}$ Although it seems reasonable to assume that greater equality within the household leads to higher use of maternal health care services, this factor has not been explored for Nepal. We know little about how intrahousehold relations constrain or facilitate access to health care, or about the dimensions of women's position that are most critical for achieving increased use.

In this study, we examine the influence of four indicators of women's household position on the receipt of skilled antenatal and delivery care: their involvement in decision making about their own health care and about large house- 
hold purchases, their employment and control over their own earnings, and their discussion of family planning with their husbands.

\section{BACKGROUND}

\section{Sociocultural Context}

Nepal is one of the poorest countries in Asia, and one of the few countries where women's life expectancy is lower than men's. ${ }^{8}$ Although Nepal is extremely culturally diverse, its population can be divided roughly into two language groups, Indo-Aryan and Tibeto-Burman.

The Indo-Aryan group is politically and culturally predominant and mainly Hindu, living mostly in the hills and southern plains (the Terai). Norms and values relating to women are generally conservative among the Indo-Aryans. The practice of purdah (seclusion of women) is prevalent, especially for newly married women from the high castes and wealthier households, and sexual purity is highly valued for women. The Tibeto-Burman group is mainly Buddhist and lives in the hills and mountains of Nepal. It has been argued that in this group women have more freedom of mobility and somewhat higher social status.

The Indo-Aryans prefer to marry outside their own villages, whereas the Tibeto-Burmans prefer to marry within the same village, thus allowing women greater access to familial and economic resources after marriage. ${ }^{9}$ However, across all Nepali cultural groups, marriage is considered to be a social contract between clans rather than a personal one between individuals. ${ }^{10}$ Following marriage, a daughter-in-law is expected to perform domestic duties under the supervision of her mother-in-law, who is usually the primary decision maker in matters of child-rearing and care of the family. ${ }^{11}$ In addition, the majority of communities in Nepal are patriarchal, and property is passed from father to son. Women lag far behind men in education, economic resources and nonagricultural employment. ${ }^{12}$

\section{Maternal Health Care Services}

Primary maternal health care is provided by the government through health posts and sub-health posts $(3,873)$, and through primary health care centers (191). At the secondary level, there are district hospitals (67), and at the tertiary level, there are zonal hospitals (10), regional and central hospitals (10) and one specialized maternity hospital. The government currently considers the numbers of facilities offering specialized maternal, newborn and child health care to be adequate, but recognizes a need to strengthen capacity, especially in terms of quality of care and management of major obstetric complications. ${ }^{13}$

The affordability of maternal care depends on the type of care and the level of the health facility. In the rural Banke district, for example, the cost of a vaginal delivery in a hospital ranges from 300 to 3,000 rupees (mean, 600 rupees, or US\$11). ${ }^{14}$ The cost of a cesarean delivery is much higher, between 1,000 and 13,000 rupees (mean, 5,360 rupees, or US\$96). It is government policy to provide antenatal care free of charge, except for medicine.

\section{METHODS}

This study analyzes data from the 2001 Nepal Demographic and Health Survey (DHS), which employed a nationally representative sample of 8,400 ever-married women aged 15-49. The present analysis is restricted to the 4,695 women who were currently married and had given birth in the three years preceding the survey.

The study variables can be grouped into four categories: indicators of women's household position, women's social and demographic characteristics, their perceptions of the geographic and economic accessibility of maternal health care, and the receipt of skilled antenatal and delivery care.

\section{Women's Household Position}

Recent attempts to define the relationships between indicators of women's social position and their reproductive health, particularly use of contraceptives, have identified a number of complexities. First, women's position is multidimensional, and different dimensions commonly show diverse relationships with reproductive health outcomes. ${ }^{15}$ Second, because these indicators may have different meanings in different sociocultural contexts, they must be carefully conceptualized, understood and interpreted. ${ }^{16}$ In particular, a predominant focus on "autonomy" in the demographic and reproductive health literature has been criticized as inappropriate in the context of South Asia. ${ }^{17}$ Third, contextual factors modulate the effect of individual characteristics, so the implications of particular indicators of women's position may vary significantly between settings. ${ }^{18}$

Drawing on these conceptual insights, we selected three dimensions of women's position for which information was collected in the Nepal DHS: their participation in household decision making, whether they were employed and had influence over the use of their earnings, and whether they discussed family planning with their husbands.

Other reproductive health research in South Asia has considered women's involvement in decision making to be an important aspect of their household position. ${ }^{19}$ The 2001 survey asked women whether they were involved in decision making in four areas: the kinds of food to cook each day, daily household purchases, their own health care and large household purchases.

More than $80 \%$ of DHS respondents reported deciding what food to cook either alone or in conjunction with another family member. More than $40 \%$ of women reported being involved in decisions on daily household purchases. These data are indicative of women's influence over routine household activities. In contrast, women's participation in decisions on their own health care and on large purchases was less common. Therefore, we focused on these two decision-making variables, for which we created the dichotomous categories of "involved in final decision (has the final say alone or jointly)" and "not involved in final decision (another individual has the final say)." In Nepal, there is a strong sense of family "togetherness" and individual identity is closely tied to the family, so decisions often involve complex ne- 
gotiations. ${ }^{20}$ Measuring whether a woman is involved in the final decision making is therefore a more suitable measure than whether or not she is the sole decision maker.

Women's economic dependency has long been understood to be a major factor in structuring inequalities between men and women. ${ }^{21}$ Hence, control over financial resources is often considered a central dimension when measuring women's household position. Getting access to maternal health care may require a financial outlay (for transportation, medicines and, in some cases, consultation), so we hypothesize that a woman's ability to pay for these services with her own earnings is an important determinant of access. The DHS asked women four questions relating to employment and control over earnings: "Aside from your own housework, are you currently working?"; "Have you done any work in the past 12 months?"; "Are you paid in cash or kind for this work or are you not paid at all?"; and "Who mainly decides how the money you earn will be used?" Answers were categorized into a trichotomous variable: not working, working and had no control over earnings (including those who worked without earning any cash income), and working and had control over earnings. Women who were currently working or who had worked within the 12 months prior to the survey were considered to be working.

The closeness of the husband-wife bond and the degree of communication between spouses have also been suggested to be an important dimension of women's household position, ${ }^{22}$ because conjugal intimacy is generally discouraged in South Asia and the husband represents a direct avenue to household resources. The survey asked women how often they had talked to their husbands about family planning in the past year, and answers were dichotomized as never and once or more. Discussion of this topic obviously depends on a number of factors, including exposure to information on reproductive health and the desire for fertility control. However, because our sample consisted of women who had recently given birth, and because contraception is widely promoted in Nepal, ${ }^{23}$ whether the couple had discussed family planning is likely to be a reasonable proxy for communication.

\section{Social and Demographic Characteristics}

A number of social and demographic characteristics were considered in the analysis, including women's age and number of children ever born. Because community norms and values influence individual behavior, we also assessed the place of residence (urban or rural) and region of residence (Terai, hill or mountain). Education has been consistently related both to use of maternal and child health services and to positive health outcomes, though the routes of causation are not always clear. ${ }^{24}$ We categorized women's education levels as none, primary, and secondary or higher. Indicators of the household's socioeconomic circumstances included husband's education and occupation, as well as a computed index of socioeconomic status based on access to piped water and electricity and ownership of a radio.

\section{Perception of the Accessibility of Care}

The distance women must travel to health facilities and the availability of transport options can have a significant impact on appropriate and timely use, as can user fees and household economic status. ${ }^{25}$ However, perceptions of ac-

\begin{tabular}{|c|c|c|c|c|c|}
\hline \multirow[t]{2}{*}{ Characteristic } & \multirow[t]{2}{*}{$N$} & \multicolumn{2}{|c|}{$\begin{array}{l}\text { Involved in decision } \\
\text { making }\end{array}$} & \multirow{2}{*}{$\begin{array}{l}\text { Working } \\
\text { and had } \\
\text { influence } \\
\text { over use of } \\
\text { earnings }\end{array}$} & \multirow{2}{*}{$\begin{array}{l}\text { Discussed } \\
\text { family } \\
\text { planning } \\
\text { with husbano } \\
\text { at least } \\
\text { once§ }\end{array}$} \\
\hline & & $\begin{array}{l}\text { Own } \\
\text { health } \\
\text { caret }\end{array}$ & $\begin{array}{l}\text { Large } \\
\text { purchases } ¥\end{array}$ & & \\
\hline Total & 4,695 & 25.4 & 27.7 & 7.1 & 51.3 \\
\hline \multicolumn{6}{|l|}{ Age } \\
\hline $15-19$ & 375 & $8.9^{* * *}$ & $9.4^{* * *}$ & $3.0^{* * *}$ & $48.7^{* * *}$ \\
\hline $20-24$ & 1,364 & 21.0 & 20.0 & 6.7 & 53.7 \\
\hline $25-29$ & 1,338 & 28.5 & 30.7 & 7.2 & 52.5 \\
\hline $30-34$ & 839 & 27.9 & 35.1 & 10.4 & 55.6 \\
\hline$\geq 35$ & 779 & 32.9 & 37.7 & 6.6 & 41.7 \\
\hline \multicolumn{6}{|c|}{ No. of children ever born } \\
\hline 1 & 984 & $16.6^{* * *}$ & $14.9^{* * *}$ & $5.6^{* * *}$ & $47.9^{*}$ \\
\hline $2-3$ & 1,884 & 27.0 & 28.9 & 8.6 & 53.5 \\
\hline $4-5$ & 1,095 & 28.7 & 33.3 & 6.6 & 53.0 \\
\hline$\geq 6$ & 732 & 27.8 & 34.2 & 6.4 & 47.7 \\
\hline \multicolumn{6}{|l|}{ Residence } \\
\hline Urban & 328 & 30.2 & 27.4 & $18.9^{* * *}$ & $65.8^{* * *}$ \\
\hline Rural & 4,367 & 25.0 & 33.3 & 6.3 & 50.2 \\
\hline \multicolumn{6}{|l|}{ Region } \\
\hline Terai & 2,382 & $22.2^{* * *}$ & $26.9^{* *}$ & $7.6^{* * *}$ & 53.1 \\
\hline Hill & 1,957 & 30.1 & 30.4 & 7.2 & 50.4 \\
\hline Mountain & 356 & 22.2 & 19.2 & 3.4 & 44.8 \\
\hline \multicolumn{6}{|c|}{ Woman's education } \\
\hline None & 3,925 & $25.1^{* *}$ & $38.5^{*}$ & $5.9^{* * *}$ & $47.6 * *$ \\
\hline Primary & 585 & 24.4 & 39.5 & 11.5 & 68.0 \\
\hline$\geq$ secondary & 185 & 36.3 & 50.2 & 20.3 & 76.6 \\
\hline \multicolumn{6}{|c|}{ Husband's education } \\
\hline None & 1,623 & 24.7 & 29.4 & $6.5^{* * *}$ & $41.5^{* * *}$ \\
\hline Primary & 1,161 & 28.1 & 29.0 & 7.4 & 50.9 \\
\hline$\geq$ secondary & 1,806 & 25.3 & 26.4 & 7.5 & 60.4 \\
\hline Missing & 105 & na & na & na & na \\
\hline \multicolumn{6}{|c|}{ Husband's occupation } \\
\hline Unskilled & 2,921 & $20.5^{* * *}$ & $24.7^{* * *}$ & $4.8^{* * *}$ & $50.2^{* * *}$ \\
\hline Skilled & 1,360 & 34.0 & 33.3 & 12.1 & 53.6 \\
\hline Professional & 237 & 28.3 & 32.7 & 10.8 & 66.7 \\
\hline Missing & 177 & na & na & na & na \\
\hline \multicolumn{6}{|c|}{ Socioeconomic status } \\
\hline Low & 2,091 & $26.2^{* * *}$ & $30.9 * * *$ & $6.7^{* * *}$ & $47.0^{* * *}$ \\
\hline Middle & 2,181 & 24.7 & 25.7 & 7.2 & 54.4 \\
\hline High & 114 & 43.1 & 45.6 & 25.8 & 67.7 \\
\hline Missing & $309+t$ & na & na & na & na \\
\hline \multicolumn{6}{|c|}{ Geographic accessibility of care } \\
\hline Big problem & 2,489 & $22.5^{* * *}$ & $25.5^{* *}$ & $5.2^{* * * *}$ & $46.1^{* * *}$ \\
\hline No/little problem & 2,206 & 28.9 & 30.2 & 9.4 & 57.2 \\
\hline \multicolumn{6}{|c|}{ Economic accessibility of care } \\
\hline Big problem & 3,215 & $23.9^{* *}$ & $25.6^{* *}$ & $6.0^{* * *}$ & $45.9^{* * *}$ \\
\hline No/little problem & 1,480 & 29.0 & 30.4 & 10.0 & 63.0 \\
\hline
\end{tabular}

${ }^{*} p<$ <.05. ${ }^{* *} p<.01 .{ }^{* * *} p<.001$. †Responses missing for 17 women. \#Responses missing for 13 women. §Responses missing for four women. $†+T h r e e$ hundred and seven women were not living at their usual address and were not asked this question; responses were missing for two other cases. Notes: $F$ tests performed for differentials across subgroups. na=not applicable. 


\begin{tabular}{|c|c|c|c|}
\hline Characteristic & $\mathrm{N}$ & $\begin{array}{l}\text { Antenatal } \\
\text { care }\end{array}$ & $\begin{array}{l}\text { Delivery } \\
\text { care }\end{array}$ \\
\hline Total & 4,694 & 39.0 & 13.3 \\
\hline \multicolumn{4}{|l|}{ Age } \\
\hline $15-19$ & 375 & $49.1^{* * *}$ & $19.7^{* * *}$ \\
\hline $20-24$ & 1,364 & 46.7 & 17.1 \\
\hline $25-29$ & 1,337 & 41.8 & 13.3 \\
\hline $30-34$ & 839 & 33.5 & 11.1 \\
\hline$\geq 35$ & 779 & 21.7 & 6.3 \\
\hline \multicolumn{4}{|c|}{ No. of children ever born } \\
\hline 1 & 984 & $55.9^{* * *}$ & $27.2^{* * *}$ \\
\hline $2-3$ & 1,884 & 43.8 & 13.5 \\
\hline $4-5$ & 1,094 & 29.1 & 6.6 \\
\hline$\geq 6$ & 732 & 18.6 & 4.3 \\
\hline \multicolumn{4}{|l|}{ Residence } \\
\hline Urban & 328 & $79.3^{* * *}$ & $53.2^{* * *}$ \\
\hline Rural & 4,366 & 36.0 & 10.4 \\
\hline \multicolumn{4}{|l|}{ Region } \\
\hline Terai & 2,382 & $42.8^{*}$ & $15.0^{* *}$ \\
\hline Hill & 1,956 & 36.6 & 12.9 \\
\hline Mountain & 356 & 26.3 & 4.6 \\
\hline \multicolumn{4}{|c|}{ Woman's education } \\
\hline None & 3,924 & $31.7^{* * *}$ & $7.8^{* * *}$ \\
\hline Primary & 585 & 71.6 & 32.8 \\
\hline$\geq$ secondary & 185 & 90.8 & 66.1 \\
\hline \multicolumn{4}{|c|}{ Husband's education } \\
\hline None & 1,622 & $24.8^{* * *}$ & $5.1 * * *$ \\
\hline Primary & 1,161 & 33.2 & 8.6 \\
\hline$\geq$ secondary & 1,806 & 55.4 & 23.8 \\
\hline Missing & 105 & na & na \\
\hline \multicolumn{4}{|c|}{ Husband's occupation } \\
\hline Unskilled & 2,920 & $30.5^{* * *}$ & $7.5^{* * *}$ \\
\hline Skilled & 1,360 & 51.4 & 22.0 \\
\hline Professional & 237 & 66.3 & 38.0 \\
\hline Missing & 177 & na & na \\
\hline \multicolumn{4}{|c|}{ Socioeconomic status } \\
\hline Low & 2,090 & $28.7^{* * *}$ & $5.6 * * *$ \\
\hline Middle & 2,181 & 45.2 & 17.6 \\
\hline High & 114 & 89.6 & 61.8 \\
\hline Missing & $309+$ & na & na \\
\hline \multicolumn{4}{|c|}{ Geographic accessibility of care } \\
\hline Big problem & 2,488 & $29.9 * * *$ & $8.2^{* * *}$ \\
\hline No/little problem & 2,206 & 49.3 & 19.1 \\
\hline \multicolumn{4}{|c|}{ Economic accessibility of care } \\
\hline Big problem & 3,214 & $30.6^{* * *}$ & $8.3^{* * *}$ \\
\hline No/little problem & 1,480 & 57.1 & 24.4 \\
\hline
\end{tabular}

cessibility can be affected by sociocultural factors. To control for all of these factors, we assessed responses to the following question: "When you are sick and want to get medical advice or treatment, is each of the following a big problem, a small problem or not a problem for you? 1) distance to the health facility and 2) getting the money needed to go." Answers were dichotomized as a big problem versus a little problem or not a problem.

\section{Use of Maternal Health Care}

We assessed the outcome variables of receipt of skilled antenatal care (at least once during the last pregnancy) and receipt of skilled delivery care for the last birth. The definition of skilled personnel was based on World Health Organization guidelines and included obstetricians and gynecologists, general practitioners, medical officers (with five years of training), midwives and nurses (with three years of training) and auxiliary midwives (with 18 months of training). 26

\section{Statistical Analysis}

We first examined the bivariate relationships of women's social and demographic variables and their perceptions of health care accessibility with the four indicators of their household position and with their use of skilled antenatal and delivery care. We then looked for potential bivariate associations between the indicators of women's household position and the two health care outcomes. Next, multivariate logistic regression models were developed to identify associations between the indicators of women's household position and their use of skilled maternal health care, as well as between women's education level and use of care. Our models controlled for a series of variables, including age and number of children ever born, residence, education, socioeconomic status and accessibility of health care. The weighted and clustered nature of the sample was accounted for by using the svylogit command in Stata version $7 .{ }^{27}$

\section{RESULTS}

\section{Bivariate Analysis}

- Social and demographic characteristics and household position. In all, $25 \%$ of women reported being involved in the final decision (either alone or with others) regarding their own health care, and 28\% reported involvement in large household purchases (Table 1, page 19). Although 84\% of all respondents were working, the vast majority of these women (91\%) had no influence over the use of earnings, most being unpaid agricultural workers (not shown). Only $7 \%$ of all women were working and had influence over how their earnings were spent. About half reported having discussed family planning with their husbands in the past year.

Each of the four measures of women's household position varied significantly according to social and demographic characteristics. The percentage of women involved in decision making on their own health care or on large purchases rose with increasing age, ranging from 9\% for 15-19-yearolds to $33-38 \%$ for women aged 35 or older. The percentage of women who worked and had influence over how their earnings were spent increased with age up to 30-34 years (rising from 3\% to 10\%), but declined for the oldest agegroup. Discussion of family planning showed a different pattern, with the highest proportion of women reporting discussion being in the middle age-groups (53-56\%). Findings for the number of children ever born were similar to those for women's age: Women reporting only one child were significantly less likely to be involved in decision making 


\begin{tabular}{|c|c|c|c|}
\hline Indicator & $N$ & $\begin{array}{l}\text { Antenatal } \\
\text { care }\end{array}$ & $\begin{array}{l}\text { Delivery } \\
\text { care }\end{array}$ \\
\hline \multicolumn{4}{|c|}{$\begin{array}{l}\text { Involvement in decision making on } \\
\text { own health care }\end{array}$} \\
\hline No & 3,486 & 38.4 & $12.7^{*}$ \\
\hline Yes & 1,191 & 40.1 & 15.5 \\
\hline Missing & 17 & na & na \\
\hline \multicolumn{4}{|c|}{$\begin{array}{l}\text { Involvement in decision making on } \\
\text { large purchases }\end{array}$} \\
\hline No & 3,379 & 37.9 & 12.6 \\
\hline Yes & 1,302 & 41.9 & 15.1 \\
\hline Missing & 13 & na & na \\
\hline \multicolumn{4}{|c|}{$\begin{array}{l}\text { Employment and influence } \\
\text { over use of earnings }\end{array}$} \\
\hline Not working & 772 & $58.4^{* * *}$ & $29.0^{* * *}$ \\
\hline $\begin{array}{l}\text { Working and ha } \\
\text { no influence }\end{array}$ & 3,587 & 32.9 & 8.8 \\
\hline $\begin{array}{l}\text { Working and } \\
\text { had influence }\end{array}$ & 335 & 59.0 & 25.7 \\
\hline \multicolumn{4}{|c|}{$\begin{array}{l}\text { Discussion of family } \\
\text { planning with husband }\end{array}$} \\
\hline Never & 2,284 & $32.0^{* * *}$ & $9.7^{* * *}$ \\
\hline At least once & 2,406 & 45.7 & 16.8 \\
\hline Missing & 4 & na & na \\
\hline
\end{tabular}

or to have influence over the use of their earnings than were women reporting two or more children.

Higher proportions of urban women than of rural women reported working and having influence over use of their earnings (19\% vs. $6 \%$ ), and having discussed family planning with their husbands (66\% vs. 50\%), though there were no differences between the groups in the measures of decision making. Region of residence, however, showed significant differences for all indicators except the discussion of family planning. Women who lived in the hills were the most likely to report involvement in decision making (30\% for each measure). The proportions of hill and Terai residents who worked and had influence over earnings (7-8\%) were similar; the proportion among mountain residents was much lower (3\%).

Women's education showed a positive association with all measures, though the patterns varied. Compared with women who had no education or only primary schooling, those with a secondary or higher education were more likely to report involvement in decisions on their health care (36\% vs. $24-25 \%$ ) and on large purchases (50\% vs. $39-40 \%)$. In contrast, the proportion working and having influence over earnings and the proportion reporting discussion of family planning rose with each level of education.

Husband's level of education showed fewer significant relationships. The proportion of women who worked and had influence over earnings was slightly (and significantly) higher among those whose husbands were better educated, though the proportion of women who did not work at all was also higher in these subgroups (not shown). The discussion of family planning was more common among women whose husbands had a secondary or higher education than among those whose spouses had no education or only primary schooling ( $60 \%$ vs. $42-51 \%$ ).

Husband's occupation showed significant differences with all four indicators of women's household position. Women whose husbands were unskilled workers were the least likely to report involvement in either type of decision making (21-25\%), working and having influence over earnings (5\%) and discussing family planning (50\%). For the measure of socioeconomic status, women in high-status households were more likely than those in low- and middle-status households to report involvement in either type of decision making (43-46\% vs. 25-31\%), influence over use of their earnings (26\% vs. $7 \%$ ) and discussion of family planning (68\% vs. $47-54 \%)$.

Women's perceptions of the geographic and economic accessibility of maternal health care were associated with all four indicators of women's household position, possibly reflecting the confounding influence of the socioeconomic variables. Women who characterized accessibility as a "big problem" were significantly less likely to report decision-making involvement, influence over use of their earnings or discussion of family planning.

- Social and demographic characteristics and maternal health care. Overall, the percentage of women receiving skilled maternal health care is low in Nepal, with 39\% using antenatal care and 13\% delivery care (Table 2). Large disparities are evident across subgroups of women, although the patterns of use are similar for the two types of care.

The variables of women's age and number of children ever born show similar trends of health care use. The proportion of women using skilled antenatal care and skilled delivery care fell from $49 \%$ and $20 \%$, respectively, among 15-19-year-olds to $22 \%$ and $6 \%$, respectively, among women aged 35 or older. Likewise, the proportion using these two types of care dropped from $56 \%$ and $27 \%$, respectively, among women who had had one child to $19 \%$ and $4 \%$, respectively, among those who had had six or more children.

As expected, higher proportions of urban women than of rural women received antenatal care (79\% vs. 36\%) and delivery care (53\% vs. 10\%). Differences in use across regions were also significant, with women living in the Terai being more likely than those living in the mountains or hills to receive antenatal (43\% vs. $26-37 \%$ ) or delivery care (15\% vs. 5-13\%).

Women's education had a strong, positive association with the receipt of skilled care. The proportion of women using antenatal care and delivery care rose from $32 \%$ and $8 \%$, respectively, among those with no education to $91 \%$ and $66 \%$, respectively, among those with secondary or higher education, though there was a large differential between the two types of care. Husband's education showed a similar pattern.

Receipt of skilled care also varied with husband's occupation, with the proportion of women receiving such care being highest among those whose husbands were profes- 
sional or skilled workers. Particularly large differentials were found according to socioeconomic status. Women in highstatus households were more likely than those in low- and middle-status households to use either antenatal care (90\% vs. $29-45 \%$ ) or delivery care (62\% vs. $6-18 \%$ ).

Receipt of services was also associated with their perceived accessibility. Women who reported that geographic or economic accessibility was a "big problem" were significantly less likely to receive skilled maternal health care, especially during delivery.

- Household position and maternal health care. Our bivariate analysis examining the relationship between the indicators of women's household position and the receipt of skilled maternal health care (Table 3, page 21 ) revealed that women's involvement in decision making for their own health care was not associated with the use of skilled antenatal care; this indicator did show an association with skilled delivery care, but the differential was small.

In contrast, the variable of employment and influence over earnings showed significant differences for both antenatal and delivery care. Women who worked and had no influence over earnings were the least likely to have received either type of care (33\% and 9\%, respectively), whereas levels of use were much higher among nonworkers (58\% and $29 \%$ ) and women who worked and had influence over earnings (59\% and 26\%).

The remaining indicator of women's household positiondiscussing family planning —also showed significant differences in health care use. Forty-six percent of women who had discussed family planning at least once received antenatal care and $17 \%$ received delivery care; among those who did not discuss it, $32 \%$ and $10 \%$, respectively, received care.

\section{Multivariate Analysis}

To control for the confounding influence of the social, demographic and accessibility variables, we developed a series of multivariate logistic regression models to identify the independent associations between the indicators of women's household position and the receipt of antenatal and delivery care. Similar models were used to identify associations between women's education level and use of maternal health care.
- Household position and antenatal care. For each of the four indicators of women's household position, we conducted a series of regression models assessing the odds of receipt of skilled antenatal care while controlling for different sets of confounding variables (Table 4). Compared with women who were not involved in decision making on their own health care, those who were involved did not have significantly elevated odds of using antenatal care either before or after controls were added for potential confounders. However, after adjustment for all potential confounders, women who were involved in decision making regarding large purchases had significantly higher odds of receiving such care than did those who were not involved (odds ratio, 1.3).

Two sets of odds ratios were derived from the regression series for the indicator of women's employment and control over earnings. Working women who had influence over how their earnings were used were significantly more likely to receive antenatal care than were those who worked but had no control over their earnings, before and after the effects of confounding variables were accounted for (odds ratios, 2.9 and 1.8, respectively). Nonworking women were also more likely to get such care than were workers with no influence over use of their earnings, though the odds (and the level of significance) declined sharply after adjustment for all potential confounders (1.5). When compared with nonworking women, those who worked and had influence were no more likely to have received skilled antenatal care (not shown).

The discussion of family planning also showed a consistently significant association with receipt of antenatal care. In the final model, the odds of receiving care were $41 \%$ higher among women who reported some discussion with their husbands than among those who reported none (1.4).

- Household position and delivery care. The relationships between the indicators of women's household position and receipt of skilled delivery care were broadly similar to those between the indicators and antenatal care (Table 5). Neither decision-making indicator was associated with receipt of skilled delivery care after we controlled for all confounders. Both workers who had some control over earnings and nonworkers had higher odds of receiving skilled delivery care than did women who worked but had no con-

\begin{tabular}{|c|c|c|c|c|c|}
\hline Model & $\begin{array}{l}\text { Involved in decision } \\
\text { making on own } \\
\text { health care } \\
\text { vs. } \\
\text { not involved }\end{array}$ & $\begin{array}{l}\text { Involved in decision } \\
\text { making on large } \\
\text { purchases } \\
\text { vs. } \\
\text { not involved }\end{array}$ & $\begin{array}{l}\text { Working and had } \\
\text { influence over use } \\
\text { of earnings vs. } \\
\text { working and had } \\
\text { no influencet }\end{array}$ & $\begin{array}{l}\text { Not working } \\
\text { vs. } \\
\text { working and had } \\
\text { no influence over } \\
\text { use of earnings }\end{array}$ & $\begin{array}{l}\text { Discussed family } \\
\text { planning with } \\
\text { husband at } \\
\text { least once vs. } \\
\text { never }\end{array}$ \\
\hline Unadjusted & 1.11 & 1.19 & $2.93^{* * *}$ & $2.87^{* * *}$ & $1.79 * * *$ \\
\hline Adjusted for age and no. of children & $1.23^{*}$ & $1.48^{* * *}$ & $2.93^{* * *}$ & $2.47^{* * *}$ & $1.88^{* * *}$ \\
\hline Adjusted for residence and region & 1.11 & 1.16 & $2.37^{* * *}$ & $2.15^{* * *}$ & $1.69^{* * *}$ \\
\hline Adjusted for woman's education & 1.07 & 1.15 & $2.28^{* * *}$ & $2.30^{* * *}$ & $1.48^{* * *}$ \\
\hline Adjusted for socioeconomic status $\ddagger$ & 1.02 & $1.20^{*}$ & $2.48^{* * *}$ & $2.32^{* * *}$ & $1.55^{* * *}$ \\
\hline Adjusted for accessibility of health care & 1.02 & 1.12 & $2.55^{* * *}$ & $2.44^{* * *}$ & $1.54^{* * *}$ \\
\hline Adjusted for all potential confounders & 1.08 & $1.25^{*}$ & $1.83^{* * *}$ & $1.50^{* *}$ & $1.41^{* * *}$ \\
\hline
\end{tabular}

${ }^{*} \mathrm{p}<.05 .{ }^{* *} \mathrm{p}<.01 .{ }^{* * *} \mathrm{p}<.001 . \dagger$ A single regression series was used to produce two sets of odds ratios for the indicator of woman's employment and influence over earnings. $¥$ Adjusted for husband's education, husband's occupation and socioeconomic status. 


\begin{tabular}{|c|c|c|c|c|c|}
\hline Model & $\begin{array}{l}\text { Involved in decision } \\
\text { making on own } \\
\text { health care } \\
\text { vs. } \\
\text { not involved }\end{array}$ & $\begin{array}{l}\text { Involved in decision } \\
\text { making on large } \\
\text { purchases } \\
\text { vs. } \\
\text { not involved }\end{array}$ & $\begin{array}{l}\text { Working and had } \\
\text { influence over use } \\
\text { of earnings vs. } \\
\text { working and had } \\
\text { no influencet }\end{array}$ & $\begin{array}{l}\text { Not working } \\
\text { vs. } \\
\text { working and had } \\
\text { no influence over } \\
\text { use of earnings }\end{array}$ & $\begin{array}{l}\text { Discussed family } \\
\text { planning with } \\
\text { husband at } \\
\text { least once vs. } \\
\text { never }\end{array}$ \\
\hline Unadjusted & $1.26^{*}$ & 1.22 & $3.58^{* * *}$ & $4.23^{* * *}$ & $1.88^{* * *}$ \\
\hline Adjusted for age and no. of children & $1.45^{* * *}$ & $1.59 * * *$ & $3.54^{* * *}$ & $3.72^{* * *}$ & $2.06^{* * *}$ \\
\hline Adjusted for residence and region & 1.23 & 1.12 & $2.51^{* * *}$ & $2.91^{* * *}$ & $1.69^{* * *}$ \\
\hline Adjusted for woman's education & 1.18 & 1.14 & $2.36^{* * *}$ & $3.08^{* * *}$ & $1.35^{* *}$ \\
\hline Adjusted for socioeconomic status $¥$ & 1.09 & 1.18 & $2.48^{* * *}$ & $2.31^{* * *}$ & $1.55^{* * *}$ \\
\hline Adjusted for accessibility of health care & 1.15 & 1.16 & $3.01^{* * *}$ & $3.50^{* * *}$ & $1.54^{* * *}$ \\
\hline Adjusted for all potential confounders & 1.19 & 1.21 & $1.59^{*}$ & $1.76^{* * *}$ & $1.34^{*}$ \\
\hline
\end{tabular}

trol over their earnings (1.6 and 1.8, respectively). Discussion of family planning was found to be consistently associated with delivery care, with women who had discussed it with their husbands having 34\% higher odds of receiving such care than those who had not once the effects of all potential confounders were accounted for.

These findings suggest that a woman's receipt of skilled maternal health care may be related to her position within her household. However, the associations are not consistent across the indicators of household position, and they require careful interpretation. Furthermore, whatever effects are present are moderate. Several other variables, notably women's education, household socioeconomic status, the economic accessibility of health care and urban-rural residence, showed far stronger associations with receipt of skilled care (not shown).

-Women's education and maternal health care. Regression analysis of the associations between women's education level and their receipt of skilled antenatal and delivery care yielded very strong findings (Table 6). Even in the models that controlled for all confounding variables, women with secondary or higher education had dramatically higher odds of using antenatal or delivery care than did women having no schooling or an incomplete primary education (5.6 and 5.1, respectively). Likewise, women with a primary school education were more likely than those without one to receive antenatal or delivery care (2.4 and 2.1, respectively). Clearly, women's schooling has played an important role in their use of health care, but how it does so is a complex question. Compared with the unadjusted models in Table 6 , models that controlled for the discussion of family planning showed reduced odds ratios, particularly for the regression series that examined secondary schooling. This suggests that part of the effect of education operates via differences in communication patterns between partners. However, the large residual effects indicate that education acts through other factors as well.

Though space limitations preclude detailed presentation of the results, it is important to highlight the role of the household financial situation in influencing women's use of maternal health care. After controlling for all confounders, women of high socioeconomic status had odds of using antenatal care that were more than four times as high as those of women of low socioeconomic status, and their odds of using delivery care were more than three times as high (not shown). Furthermore, although the geographic accessibility of health care lost its significance after the effect of potential confounders was accounted for, the economic accessibility of health care retained its association with receipt of maternal care.

\begin{tabular}{|c|c|c|c|c|}
\hline \multirow[t]{2}{*}{ Model } & \multicolumn{2}{|c|}{ Antenatal care } & \multicolumn{2}{|l|}{ Delivery care } \\
\hline & $\begin{array}{l}\text { Primary } \\
\text { vs. none/ } \\
\text { incomplete } \\
\text { primary }\end{array}$ & $\begin{array}{l}\text { Secondary } \\
\text { vs. none/ } \\
\text { incomplete } \\
\text { primary }\end{array}$ & $\begin{array}{l}\text { Primary } \\
\text { vs. none/ } \\
\text { incomplete } \\
\text { primary }\end{array}$ & $\begin{array}{l}\text { Secondary } \\
\text { vs. none/ } \\
\text { incomplete } \\
\text { primary }\end{array}$ \\
\hline Unadjusted & $5.44^{* * *}$ & $21.36^{* * *}$ & $5.65^{* * *}$ & $22.57^{* * *}$ \\
\hline Adjusted for age and no. of children & $4.28^{* * *}$ & $14.77^{* * *}$ & $4.48^{* * *}$ & $15.69^{* * *}$ \\
\hline Adjusted for residence and region & $4.90^{* * *}$ & $18.38^{* * *}$ & $4.46^{* * *}$ & $18.84^{* * *}$ \\
\hline Adjusted for socioeconomic statust & $3.40^{* * *}$ & $10.57^{* * *}$ & $3.15^{* * *}$ & $9.23^{* * *}$ \\
\hline Adjusted for accessibility of health care & $4.14^{* * *}$ & $14.25^{* * *}$ & $4.27^{* * *}$ & $15.48^{* * *}$ \\
\hline Adjusted for decision-making indicators & $5.46^{* * *}$ & $21.20^{* * *}$ & $5.62^{* * *}$ & $22.06 * * *$ \\
\hline Adjusted for woman's employment & $4.97^{* * *}$ & $16.31^{* * *}$ & $4.92^{* * *}$ & $16.41^{* * *}$ \\
\hline Adjusted for discussion of family planning & $5.09^{* * *}$ & $19.40^{* * *}$ & $5.34^{* * *}$ & $20.91 * * *$ \\
\hline Adjusted for all potential confounders & $2.36^{* * *}$ & $5.56^{* * *}$ & $2.11^{* * *}$ & $5.07^{* * *}$ \\
\hline
\end{tabular}




\section{DISCUSSION}

Many studies and policies have been based on the assumption that if women were more involved in household decision making and had more control over financial resources, they would be more likely to use health services and, hence, to have better health outcomes. However, results from this study reveal a more complex picture, showing diverse relationships between the outcomes of interest and the four indicators of women's household position. Our findings help identify both the changes in women's position needed to improve health care use and the usefulness of various empirical measures of their position. These results also identify the most important current barriers to the uptake of maternal health care services in Nepal.

The uptake of skilled health care depends on both demand (which implies a perceived need and the recognition that available services are valuable and appropriate) and the ability to act on that demand. The gender relations in any particular setting will affect these factors. Other elements, largely unrelated to gender relations, may also exert a critical influence on demand and the ability to act. Furthermore, increases in the uptake of reproductive health services may occur in the absence of any significant change in women's position, as shown by the rise in contraceptive use in northern India. ${ }^{28}$ Differences between groups of women in their use of maternal health services may be further influenced by factors unrelated to differences in their household position.

Our analysis found a positive association between a woman's discussion of family planning with her husband and the receipt of both antenatal and delivery care. This association could be explained by the fact that individuals who discuss family planning tend to be more open to modern ideas and therefore more likely to opt for skilled maternal health care. That is, the route of causation could be unrelated to intrahousehold gender relations. However, a plausible argument supported by recent qualitative work in $\mathrm{Nepa}^{29}$ is that women who discuss family planning with their husbands also communicate more about other matters, reflecting a more open, egalitarian relationship. Communication between partners about contraception may also indicate greater male involvement in matters that are traditionally identified as belonging in the "female" realm and therefore potentially stigmatizing for men. Thus, at least part of the association may reflect improvements in household gender relations that are translated into increased use of maternal health care. It seems likely that such communication would largely operate by increasing the chance that women (or couples) would act on preexisting demand for care, although it may also act to create, or solidify, demand through the exchange of information and support.

In light of this association between communication and the use of skilled health care, it is striking that the decisionmaking variables showed such weak associations. We suggest that the formulation of the questions may offer a partial explanation. Survey questions asked about who has the "final say" in decisions, and though we combined responses of "myself alone" and "joint" decision making, it is likely that the emphasis on final decision making is inappropriate in the Nepali context. Because decisions regarding the management of pregnancy are within the domain of older female relatives, and because younger females tend to exert influence in subtle, nonconfrontational ways, it is possible that women who report being involved in final decision making are actually relatively isolated, unsupported individuals, and not autonomous agents who are able to garner the household resources to meet their own needs.

In our study, women's employment did not translate clearly into greater use of maternal health care. Nepali women who work but have no control over the use of their earnings are the least likely to receive skilled antenatal or delivery care. This is not surprising, as most are from poor households and are working for the family's survival. However, even after controlling for socioeconomic status, urban or rural residence and other confounders, women who work and have influence over their earnings are no more likely to receive skilled care during pregnancy or delivery than are women who do not work.

We expected that working women with influence over earnings would have greater influence over their health care than would nonworkers, and would also be exposed to knowledge and attitudes about modern health care at their workplaces, thus leading to higher use of skilled services via both increased demand and an increased ability to act on that demand. Perhaps working women experience time constraints that reduce their opportunities for receiving antenatal care. However, this would not explain why they are no more likely than other women to get skilled delivery care. Clearly, the relationship between employment and health care use is complex, and initiatives aimed at increasing employment opportunities may not generate the assumed benefits of either improved intrahousehold gender relations or greater health care utilization. We conclude that some dimensions of a Nepali woman's household position, particularly the extent of communication with her husband, do positively affect her receipt of skilled maternal health care, but that the effects are small.

Another issue that we examined was the extent to which the current low levels of skilled maternal health care use in Nepal are explained by women's weak household position. Our findings strongly suggest that factors other than household gender inequality are the main determinants of use at the present time. Household economic status, in particular, emerged as an important factor associated with use. Although this no doubt reflects the ability to pay for services, the fact that a significant association remains after controlling for geographic and economic accessibility, and for urban or rural residence, suggests that better-off socioeconomic groups differ from their poorer counterparts in more than just disposable income. It seems likely that an important aspect of this difference lies in their perceptions regarding the need for and value of skilled maternal health services. Recent research has noted that a major shift in attitudes and aspirations among better-off families in rural Pakistan played an 
important role in their increased demand for antenatal care.

The very strong relationship between women's education and use of maternal health care also suggests that the financial and geographic accessibility of services is not the only factor. This association draws our attention to how the broader gender system, operating beyond the household, may affect care. A number of routes of causation might explain this strong effect. Earlier work in South Asia has suggested that this association may be due at least in part to a fostering of new values and attitudes that are favorable to the use of modern health care. ${ }^{30}$ Education may impart feelings of self-worth and self-confidence, which some have argued are more important in bringing about changes in health-related behavior than exposure to relevant information. ${ }^{31}$ Schooling may also increase women's receptivity to new health-related information. ${ }^{32}$ One study found that even when women knew about their obstetric complications, many chose not to seek care because of the poor quality of care they expected to receive. ${ }^{33}$ Greater education may reduce the power differential between providers and clients and lower women's reluctance to seek care. ${ }^{34}$

In addition to increasing the likelihood that women will value and desire skilled care, education may strengthen women's ability to act on this demand. The results of our multivariate models suggest that the effect of education operates in part via increased discussion between husbands and wives. Research in Nepal and elsewhere in South Asia has indicated that women seek influence within their households in subtle ways, rather than by challenging established gender and age hierarchies. Chanana pointed out that younger, educated women have a greater capacity to use "the weapons of the weak," 35 while Basu described educated women as having hidden power to influence decisions "without rocking the boat." 36

Our own analysis reveals that a low percentage of even highly educated women were involved in decision making regarding their own health. In Nepal, decisions about the management of pregnancy and childbirth traditionally come under the authority of older women, especially the mother-in-law. ${ }^{37}$ It seems likely that an educated woman would be able to use subtle means to influence her mother-in-law's decisions and at the same time introduce the family to new ideas about the value of skilled health care. A more communicative marital relationship may also increase a woman's influence within the household. ${ }^{38}$

Much of this discussion is based on informed speculation and requires additional, in-depth research for support. However, it is clear that gender relations influence the use of maternal health care in diverse ways. Though spousal communication does seem to be important, other aspects of gender relations do not relate specifically to the husbandwife relationship. A focus on women's autonomy and independence from her husband and family, which is predominant in much of the reproductive health literature, is inappropriate to this cultural setting and overlooks important dimensions of women's experience. Greater attention should be directed to the ways in which intrahousehold decision-making processes play out and to how younger women can gain influence over those familial spheres that directly affect their well-being.

\section{Conclusions}

Despite the recent efforts of international organizations and women's groups to raise the profile of maternal health as a key public health issue, this study shows a persistently grim situation for the women of Nepal. In the difficult context of debilitating structural adjustment policies and limited resources, the Safe Motherhood Initiative of the Nepal Ministry of Health has focused on the accessibility and availability of maternal health care by increasing the quality and quantity of trained health workers, and by ensuring the functioning of referral systems. ${ }^{39}$ Although these are important measures, our findings indicate that such efforts will have greater impact if the sociocultural determinants of service uptake are also addressed.

This study, as well as other recent work in the region, ${ }^{40}$ suggests that interventions to improve husband-wife communication and strengthen women's influence within households are important efforts that deserve sustained support. Yet the large effect of women's education on health care use highlights the need for programs that promote greater schooling for Nepali girls. In addition, this finding draws attention to the need to raise knowledge levels about and alter perceptions of the value of skilled maternal health care among both pregnant women and other key actors. Such shifts in perception will depend not only on changing how modern, preventive health care is viewed, but also on raising the value attached to women's health.

\section{REFERENCES}

1. Asian Development Bank (ADB), Women in Nepal, country briefing paper, Kathmandu, Nepal: ADB, 1999.

\section{Ibid.}

3. Nepal Ministry of Health, New ERA and ORC Macro, Nepal Demographic and Health Survey 2001, Calverton, MD, USA: ORC Macro, 2002.

4. Jeffery P, Jeffery R and Lyon A, Labour Pains and Labour Power: Women and Childbearing in India, London and Atlantic Highlands, NJ, USA: Zed Books, 1989; Goodburn EA, A prospective study of maternal morbidity related to delivery and the puerperium in Bangladesh, unpublished dissertation, London School of Hygiene and Tropical Medicine, London, 1997; and Mumtaz Z and Salway S, Gender, pregnancy and uptake of antenatal care services in Pakistan, Sociology of Health and Illness, 2006 (forthcoming).

5. Schuler SR, Hashemi SM and Riley AP, The influence of women's changing roles and status in Bangladesh's fertility transition: evidence from a study of credit programs and contraceptive use, World Development, 1997, 25(4):563-575; Cleland J, Kamal N and Sloggett A, Links between fertility regulation and the schooling and autonomy of women in Bangladesh, in: Jeffery R and Basu AM, eds., Girls Schooling, Women's Autonomy and Fertility Change in South Asia, New Delhi: Sage Publications, 1996, pp. 205-217; Durrant VL and Sathar ZA, Greater investments in children through women's empowerment: the key to demographic change in Pakistan, paper presented at the annual meeting of the Population Association of America, Los Angeles, CA, USA, Mar. 23-25, 2000; and Hakim A, Salway S and Mumtaz Z, Women's autonomy and uptake of contraception in Pakistan, Asia-Pacific Population Journal, 2003, 18(1):64-82. 
6. United Nations International Conference on Population and Development, Programme of Action, 1994, <http://www.unfpa.org/ icpd/icpd_poa. htm>, accessed Feb. 24, 2006.

7. Tuladhar J, Women, health and population policies, Nepal Population and Development Journal, 1997, special issue, pp. 19-36; and Rimal $\mathrm{N}$, Hindrances to family planning program: findings from Banke, Nepal, Rural and Remote Health, 2003, Vol. 3, No. 3, article no. 227.

8. ADB, 1999, op. cit. (see reference 1).

9. Acharya M and Bennett L, Women and the Subsistence Sector: Economic Participation and Household Decision-making in Nepal, Working Paper, Washington, DC: World Bank, 1983, No. 526; and Morgan SP and Niraula BB, Gender inequality and fertility in two Nepali villages, Population and Development Review, 1995, 21(3): 541-562.

10. ADB, 1999, op. cit. (see reference 1).

11. Dali SM, Thapa M and Shrestha S, Education for Nepalese women to provide improved care for their childbearing daughtersin-law, World Health Forum, 1999, 13(4):353-354.

12. ADB, 1999, op. cit. (see reference 1).

13. World Health Organization (WHO) Regional Office for SouthEast Asia, Improving Maternal, Newborn and Child Health in SouthEast Asia, New Delhi: WHO, 2005.

14. Jahn A et al., Maternity care in rural Nepal: a health service analysis, Tropical Medicine and International Health, 2000, 5(9):657-665.

15. Hakim A, Salway S and Mumtaz Z, 2003, op. cit. (see reference 5); Malhotra A, Schuler S and Boender C, Measuring Women's Empowerment as a Variable in International Development, New York: Gender and Development Group, World Bank, 2002; and Sathar ZA and Kazi S, Women's Autonomy, Livelihood and Fertility: A Study of Rural Punjab, Islamabad, Pakistan: Pakistan Institute of Development Studies, 1997

16. Malhotra A, Schuler S and Boender C, 2002, op. cit. (see reference 15); and Kabeer N, Resources, agency, achievements: reflections on the measurement of women's empowerment, Development and Change, 1999, 30(3):435-464.

17. Jeffery $P$ and Jeffery R, What's the benefit of being educated? girls' schooling, women's autonomy and fertility outcomes in Bijnor, in: Jeffery R and Basu AM, 1996, op. cit. (see reference 5), pp. 50-183; and Mumtaz Z and Salway S, I never go anywhere: extricating the links between women's mobility and uptake of reproductive health services in Pakistan, Social Science \& Medicine, 2005, 60(8):1751-1765.

18. Kabeer N, 1999, op. cit. (see reference 16).

19. Schuler SR, Hashemi SM and Riley AP, 1997, op. cit. (see reference 5); Cleland J, Kamal N and Sloggett A, 1996, op. cit. (see reference 5); Durrant VL and Sathar ZA, 2000, op. cit. (see reference 5); and Hakim A, Salway S and Mumtaz Z, 2003, op. cit. (see reference 5);

20. Acharya M and Bennett L, 1983, op. cit. (see reference 9); and Mullany BC, Hinde MJ and Becker S, Can women's autonomy impede male involvement in pregnancy health in Kathmandu, Nepal? Social Science \& Medicine, 2005, 61(9):1993-2006.

21. Standing H, Dependence and Autonomy: Women's Employment and the Family in Calcutta, London and New York: Routledge, 1991.

22. Jejeebhoy S, Women's Education, Autonomy and Reproductive Behaviour: Experience from Developing Countries, Oxford, UK Clarendon Press, 1995.

23. Sharan M and Valente TW, Spousal communication and family planning adoption: effects of a radio drama serial in Nepal, International Family Planning Perspectives, 2002, 28(1):16-25.

24. Cleland J, Maternal education and child survival: further evidence and explanations, in: Caldwell JC et al., eds., What We Know About Health Transition: The Cultural, Social and Behavioural Determinants of Health, Canberra, Australia: Health Transition Centre, Australian National University, 1990, pp. 400-419.
25. Thaddeus $S$ and Maine $D$, Too far to walk: maternal mortality in context, Social Science \& Medicine, 1994, 38(8):1091-1110; Maine $\mathrm{D}$, Why did maternal mortality decline in Matlab? Studies in Family Planning, 1996, 27(4):179-187; and Anwar ATMI, Killewo J, Chowdhury MK and Dasgupta SK, Bangladesh: Inequalities in Utilization of Maternal Health Care Services-Evidence from Matlab, Reaching the Poor Program Paper, Washington, DC: World Bank, 2004, No. 2.

26. WHO, United Nations Population Fund and UNICEF, Definition of traditional birth attendant, joint statement, Geneva: WHO, 1992.

27. StataCorp, Stata Statistical Software: Release 7.0, College Station, TX, USA: StataCorp, 2001

28. Jeffery P and Jeffery R, Killing my heart's desire: education and female autonomy in rural north India, in: Kumar N, ed., Women as Subjects: South Asian Histories, Charlottesville, VA, USA: University of Virginia Press, 1994

29. Mullany BC, Hinde MJ and Becker S, 2005, op. cit. (see reference 20)

30. Kazi S and Sathar ZA, Gender and development: searching for explanations for fertility changes in rural Pakistan, paper presented at the IUSSP seminar on comparative perspectives on fertility transition in South Asia, Islamabad, Pakistan, Dec. 17-20, 1996; and Sathar ZA and Kazi S, 1997, op. cit. (see reference 15).

31. Chanana K, Education attainment, status production and women's autonomy: a study of two generations of Punjabi women in New Delhi, in: Jeffery R and Basu AM, 1996, op. cit. (see reference 5), pp. 107-132.

32. Lindenbaum $\mathrm{S}$, The education of women and the mortality of children in Bangladesh, in: Alan C et al., eds., Disease in Populations in Transition: Anthropological and Epidemiological Perspectives, New York: Bergin and Garvey, 1990, pp. 353-370.

33. Maine D et al., The Design and Evaluation of Maternal Mortality Programs, New York: Center for Population and Family Health, School of Public Health, Columbia University, 1997.

34. Basu AM, Girls' schooling, autonomy and fertility change: what do these words mean in South Asia? in: Jeffery R and Basu AM, 1996 , op. cit. (see reference 5), pp. 48-71; Jejeebhoy S, 1995, op. cit. (see reference 22); and Starrs A, ed., The Safe Motherhood Action Agenda: Priorities for the Next Decade, New York: Family Care International, 1998.

35. Chanana K, 1996, op. cit. (see reference 31).

36. Basu AM, 1996, op. cit. (see reference 34).

37. Mullany BC, Hinde MJ and Becker S, 2005, op. cit. (see reference 20)

38. Ibid.

39. Nepal Ministry of Health, Safe Motherhood Programme in Nepal: A National Plan of Action (1994-1997), Kathmandu, Nepal: Family Health Division, Department of Health Services, Ministry of Health, 1993

40. Mumtaz Z and Salway S, 2006, op. cit. (see reference 4).

\section{RESUMEN}

Contexto: Si bien la desigualdad de género se menciona con frecuencia como un obstáculo para mejorar la salud materna en Nepal, se ha prestado poca atención al estudio de cómo influyen los factores socioculturales en el uso de los servicios de atención de la salud. En particular, se requiere un mayor estudio de los factores que explican la influencia de la posición de la mujer en el entorno de su hogar en su uso de los servicios de atención de la salud.

Métodos: Se analizaron los datos correspondientes a mujeres alguna vez casadas de 15-19 años de edad que participaron en la Encuesta Demográfica y de Salud de Nepal de 2001, para explorar tres dimensiones de la posición de la mujer en el en- 
torno familiar-la toma de decisiones en general; el empleo y la influencia que ejerce la mujer sobre sus ingresos; y las conversaciones con su cónyuge sobre la planificación familiar. Mediante modelos de regresión logística, se evaluó la relación entre estas variables y el uso de la atención prenatal especializada y la atención durante el parto.

Resultados: Pocas mujeres indicaron que habian participado en el proceso de toma de decisiones en su hogar, y aún fue menor el número de las que tenían algún tipo de control con respecto a sus propios ingresos. Sin embargo, más de la mitad manifestó que habia conversado con su pareja acerca de la planificación familiar, y los subgrupos de mujeres se diferían significativamente en cuanto a dichos indicadores de la posición de la mujer. Si bien las asociaciones significativas no fueron congruentes entre todos los indicadores, el factor de hablar con su pareja sobre planificación familiar estuvo vinculado con un aumento de las probabilidades de recibir atención prenatal especializada y atención durante el parto (razones de momios de 1,4 y 1,3, respectivamente). La educación secundaria también presentó una fuerte asociación con el uso de la atención de la salud (5,1-5,6).

Conclusiones: La desigualdad de género limita el acceso de la mujer a los servicios de atención de la salud en Nepal. Las intervenciones dirigidas a mejorar la comunicación y fortalecer la influencia de la mujer ameritan un apoyo continuo. El efecto importante de la educación de la mujer con respecto a la atención de la salud destaca la necesidad de realizar esfuerzos para incrementar la escolaridad de las jóvenes y alterar las percepciones sobre el valor de la atención de la salud materno-infantil.

\section{RÉSUMÉ}

Contexte: Bien que l'inégalité entre les sexes soit souvent citée comme obstacle à l'amélioration de la santé maternelle au Népal, l'attention est rarement dirigée sur la compréhension de la manière dont les facteurs socioculturels peuvent influencer le recours aux soins de santé. En particulier, l'effet de la position de la femme au sein de son ménage sur la mesure dans laquelle elle bénéficie de soins de santé mérite une étude plus approfondie.

Méthodes: Les données de l'EDS népalaise de 2001 relatives aux femmes de 15 à 49 ans mariées ou l'ayant jamais été ont été analysées en vue de l'examen de trois dimensions de la position des femmes au sein du ménage: prise de décision, emploi et influence sur les revenus, et discussion du planning familial avec le conjoint. Le rapport entre ces trois variables et la réception de soins prénataux et obstétricaux qualifiés a été évalué par modèles de régression logistique.

Résultats: Peu de femmes ont déclaré participer aux décisions du ménage, et moins encore disposaient du moindre contrôle sur leur propre revenu. Plus de la moitié ont toutefois déclaré avoir parlé du planning familial avec leur époux et des différences significatives sont apparues, dans les sous-groupes, au niveau de ces indicateurs de rang de la femme. Malgré l'inconstance des associations sur tous les indicateurs, la discussion du planning familial avec le conjoint s'est avérée liée à une probabilité accrue de réception de soins prénataux et obstétricaux qualifiés (rapports de probabilités 1,4 et 1,3, respectivement). L'instruction des femmes au niveau secondaire s'est également révélée fortement associée à un recours accru aux soins de santé (5,1-5,6).

Conclusions: L'inégalité entre les sexes limite l'accès des femmes aux soins de santé qualifiés au Népal. Les interventions aptes à améliorer la communication et à renforcer l'influence des femmes méritent un soutien continu. L'association forte entre l'éducation des femmes et le recours aux soins de santé souligne la nécessité d'efforts d'accroissement de la scolarisation des filles et de modification des perceptions de la valeur des soins de santé maternelle qualifiés.

\section{Acknowledgments}

This article is based on Marie Furuta's master's thesis, completed at the Centre for Population Studies, London School of Hygiene and Tropical Medicine, University of London. Her time preparing the manuscript was funded by the UK Department for International Development's Sexual and Reproductive Health Knowledge Programme. At the time of writing, Sarah Salway was a Nuffield Foundation New Career Development Fellow at the Centre for Population Studies.

Author contact:S.Salway@sheffield.ac.uk 